\title{
Challenges of National Population Census and Sustainable Development in Nigera : A Theoretical Exposition
}

\author{
Dr.Peter Ezeah, Chinwe Iyanda, and Chukwunwike Nwangwu \\ Department of Sociology/Anthropology Nnamdi Azikiwe University, Awka Nigeria.
}

\begin{abstract}
Population census undoubtedly is an important issue of concern in Nigeria. This is so because population, in terms of its size, and composition, has far-reaching implications for change, development and the quality of life in society. Since after the first census was undertaken in Nigeria, census exercises have triggered political, social, ethnic, religious controversies, geopolitical distrust and disputes that negatively affect nation building and sustainable development in the country. The sociopolitical environments around past census exercises in Nigeria are theoretically analyzed in this paper. Suggestions are offered on how to reduce negative perceptions for national census exercises in the future. It is recommended among other things that the National Population Commission (NPC) should rise to the occasion by ensuring that census data in Nigeria is not only accurate but a credible tool in National transformation and development.
\end{abstract}

\section{Introduction}

In Nigeria, population census has become a rather sensitive and controversial issue because of its implications for shaping geopolitical, state and ethnic relations and balance of power. It is the attitude of the people towards the population question, in terms of its absolute size, as it affects the states and the sub- regions that constitutes the background to the census controversies which the country has been associated with (Ottong, $\mathrm{htt}: / / \mathrm{www}$.onlineNigeria.com/population retrieved on 14/11/2013).Attempts at determining the population of Nigeria has been a very contentious issue since 1866 and establishment of the total population in the country, has been mere speculations (www.doublegist.com retrieved on April 24, 2013).

According to, Osinaike, Aiyeola and Alao (2006) census is a method used for accumulating statistical data about a population, which is acclaimed to be vital to democracy and development. In 1988, the federal government of Nigeria established the National Population Commission with the sole responsibility of conducting a reliable national population census for the country (www.population.gov.ng retrieved on 30 June, 2013). The commission has the statutory powers to collect, analyze and disseminate population/demographic data in the country. It is also mandated to undertake demographic sample surveys, compile, collate and publish migration and vital registration statistics as well as monitor the country's Population Policy. In spite of these expectations, census taking in Nigeria has continued to trigger political, social, ethnic, religious controversies, geopolitical distrust and disputes that negatively affect nation building and sustainable development. The reason for this is not far-fetched because the public perception is that higher population figures is a political weapon in a heterogeneous society like Nigeria. In other words, the higher the population figures the more government amenities, the demand for more seats in the parliament, more local governments and states to be created from a particular tribe or region. Therefore, the inherent socio-ethnic consciousness and the battle for political dominance among Nigerian geopolitical regions have continued to defeat the main aim of national population census as an instrument for strategic planning and sustainable development. Lack of accurate census figures may have contributed to Nigeria's policy summersault and under development. It is unfortunate that in this 21 st century Nigeria still does not have effective and reliable census data. Thus, when a nation does not know the proportion and the total number of its citizens, its planning process is likely to be distorted. This paper offers theoretical explanations to the socioeconomic and political issues surrounding national population exercises in Nigeria. Also, suggestions are proffered to reduce the negative perceptions associated with national population census as it relates to sustainable development in Nigeria.

\section{National Population Census}

\section{Conceptual Issues}

The term census originated from the Latin word "censere" which literally means to tax, a s s e s s value. Population census as defined by the United Nations is the total process of collecting, compiling, evaluating, analyzing and publishing or otherwise disseminating demographic, economic and social data pertaining, at a specified time, to all persons in a country or in a well delimited part of a country (South Africa Statistics, 2011). National population census can also be seen as a country's statistical operation designed for a head count of the entire human population of in country and to collect information on its main demographic, social 
and economic characteristics (Population and Societies, 2010). Osinaike, et al, (2006) explains that census is a method used for accumulating statistical data about a population, which is acclaimed to be vital to democracy and development.

Population census is one of the fundamental tasks of the government. It has become a backdrop for government's political, economic and social policy formation. Population census is one of the key planning strategies towards sustainable development and progress of a nation. It provides answer to: How many we are in terms of the total number of people living in the entire nation, "Who we are?" in terms of age, sex, education, occupation, economic activity and other crucial characteristics, as well as „Where we live" in terms of housing and access to social amenities. The answers to these questions do provide numerical profile for planning and development within a nation by providing, expanding and sustaining the infrastructures that will enhance the quality of life of the people (Mimiko, 2006). The United Nations recommends that countries take a census at least once every ten years but unfortunately Nigeria national population census exercise has not maintained this interval in its past censuses. Every census should be conducted by government of the state or country where the census is taking place, conducted at the same time (simultaneously) throughout the country and involve regular counting at specific intervals of time,. The dearth of accurate and credible statistical data has been a serious handicap to the economic and political development of Nigeria. Olusanya (1989) observed that planning is aimed at people and so inadequate knowledge of the number of the citizens, their distribution over space, their age/sex, education among other characteristic is indispensable for sustainable develo development in Nigeria

\section{Sustainable Development:}

The concept of sustainable development as defined by the Brundtland Report (1987) is the development that meets the needs of the present without compromising the ability of the future generations to meet their own needs of development (WCED, 1987). This suggests that the principal goal of sustainable development is meeting present human needs in such a way that will not jeopardize the potentials of posterity to meet their needs. Viewed from a holistic perspective, Wiedenhoeft (1981) and Padisson (2001) noted that sustainable development entails the attainment of equilibrium among three contending sub-systems -economic, social-cultural and environment

According to the more operational (practice-oriented) definition used by the World Bank, sustainable development is "a process of managing a portfolio of assets to preserve and enhance the opportunities people face". The assets that this definition refers to include not just traditionally accounted physical capital, but also natural and human capital. To be sustainable, development must provide for all these assets to grow over timeor at least not to decrease.

Sustainable development includes economic, environmental, and social sustainability, which can be achieved by rationally managing physical, natural, and human capital. Thus, sustainable development could probably be otherwise called "equitable and balanced," meaning that, in order for development to continue indefinitely, it should balance the interests of different groups of people, within the same generation and among generations, and do so simultaneously in three major interrelated areas-economic, social, and environmental. Therefore, sustainable development is about equity, equality of opportunities for well-being, as well as about comprehensiveness of objectives. Obviously, balancing so many diverse objectives of development (economic objective: growth efficiency \& stability; social objective: full employment, equity, security, education, health, participation \& cultural identity; environmental objective: healthy environment for human, rational use of renewable natural resources \& conservation of nonrenewable natural resources) is an important criteria for any nation on the road to sustainable development. Thus, to ensure that future generations inherit the necessary conditions to provide for their own welfare, our present day values must be educated enough to reflect their interests as well

More recently, the United Nations has popularized the multi-dimension term called sustainable development. This is defined as development that not only generates economic growth but distributes its benefits equitably; that regenerates the environment rather than destroys it; that empowers people rather than marginalizing them. It gives priority to the poor, enlarging their choices and opportunities, and provides for their participation in decision affecting them. Sustainable human development is pro-poor, pro-nature, pro-jobs and pro-women (Spetti, 2003). It stresses growth, but growth with employment, growth with environmental friendliness, growth with empowerment and growth with equity.

This relatively new orientation has produced concepts such as people-centered development, participatory development and sustainable human development. The concept of people-centered development states that meaningful development must be people-based, since development entails the full utilization of a nation's human and materials resources for the satisfaction of various human needs. In more specific terms, a development programme that is people centered is expected to achieve the following objectives (Chinsman, 1995): 
- Enable people to realize their potentials build self- confidence and lead lives of dignity and fulfillment

- Free people from poverty, ignorance, squalor, deprivation and exploitation recognizing that underdevelopment has wider social consequences

- Correct for existing economic, social and political injustices and oppression

\section{Brief History of Census Exercises in Nigeria}

Census exercises are bedeviled by enormous challenges in Nigeria.. It is a re-current fact that political, social and economic factors have influenced the success of census exercise in Nigeria over the years (Library of Congress, 1999). The first documented census in the entity called Nigeria was conducted by the British in 1866. Subsequently there were others censuses in 1871, 1896, 1901, 1911, 1921. All the above censuses were conducted in the Southern protectorate. The first census that included the Northern Protectorate was conducted in 1952. This attempt yielded a total population figure of 31.6 million within the current boundaries of the country as at that time (www. Nigeriacensus-history.com). The 1952 census of Nigeria indicated that the HausaFulani had the largest share of the population, and so they dominated the first post- colonial government set up after independence in 1960.The newly independent nation ordered a census to be taken in 1962, but the results showed that northerners accounted for only 30 percent of the population. A "recount" in 1963 led somewhat suspiciously to the north accounting for 67 percent of the population (Library of Congress, 1999). The 1963 census was the first after Nigeria's independence to give an officially recognized result- a total population of 55.6 million. This was widely thought to be a substantial overstatement (http://business.highbeam.com/4438/article-1G1-162101588/report-nigeria-national-population-commission-

2006).This exacerbated underlying ethnic tensions, culminating in the in the Nigerian civil war which ended in 1970. (Weeks, 2008). A census in 1973 was never accepted by the government. Not until 1991 was another census held. The official census count was 88.5 million people, well below the1 10 million that many population experts had expected $(O k o l o, 1999)$ although substantial analysis has laid the blame for that expectation on the inflated figure 19631. According to Okeibunor (1995), the 1991 census was subjected to serious controversies as accusation and counter accusation were made about falsification and inflation of figures.. Furthermore, the reported sex ratio of 101.3 was contested as it was found to defy world standard and expectation. There were complaints of undercounting and over count, and even manipulation of figures with the torrents of complaints and even rejections that trailed the current figures.

After a number of postponements, the next and latest census was taken in March, 2006. The first report was issued by the National population Commission (NPC) in December 2006. The report offers a brief defense of census procedures and, in an annex, lists provisional population total by sex and state and average growth rate over 1999-2006. The population total as of March 2006 was provisionally given as 140.0 million. The total is higher than the projected population of Nigeria in the UN's Revision estimates which show a mid- 2006 population of 134 million. On the politically sensitive matter of the relative proportions of the population in the northern and southern states, the census show a virtually unchanged division ( North- 53.3 per cent versus South 46.7 per cent in 1991; 53.6 vs 46.4 in 2006). ( http://business.highbeam.com/4438/article-1G1162101588/report-nigeria-national-population-commission-2006).

The 2006 census, unlike that of 1991, sought to lessen controversy by avoiding questions on religion or ethnicity. However, it could not escape state- level challenges to its completeness of estimation. Lagos in particular felt aggrieved (http://business.highbeam.com/4438/article1G1-162101588/report-nigeria-nationalpopulation-commission-2006). The idea to remove the ethnic and religion status of respondents was greeted with mix feelings (Lalasz,2006).Thus, The 2006 enumeration exercise was far from being a complete success. There were all kinds of complaints emanating from diverse quarters - enumerators complained of shortages of vital census materials (Weeks, 2008)

\section{Theoretical Framework}

The Social Dominance and Symbolic Interaction theories provide the framework of this paper.

\section{Social Dominance Theory}

Social Dominance Theory was first formulated by Jim Sidanius and Felicia Pratto (Sidanius and Pratto, 1999).. Social dominance theory notes that chronic group-based oppression is driven by systematic institutional and individual discrimination. That is, many social institutions (e.g., schools, organized religions, marriage practices, financial houses) and many powerful individuals disproportionately allocate desired goods-such as prestige, wealth, power, food, and health care-to members of dominant and privileged groups, while directing undesirable things such as dangerous work, disdain, imprisonment, and premature death-toward members of less powerful groups. Because institutions allocate resources on much larger scales, more systematically, and more stable than individuals generally can, social dominance theory 
regards institutional discrimination as one of the major forces creating, maintaining, and recreating systems of group-based hierarchy.

According to social dominance theory, group discrimination tends to be systematic because social ideologies help to coordinate the actions of institutions and individuals. That is, people share knowledge and beliefs that legitimize discrimination, and most often they behave as if they endorsed these ideologies. As such, people support institutions that allocate resources in accordance with those ideologies (Mitchell \& Sidanius, 1995; Pratto, Stallworth, \& Conway-Lanz, 1998; Pratto, Stallworth, \& Sidanius, 1997), and, as individuals, allocate resources in accordance with those ideologies, particularly when they are in social contexts that cue these ideologies (Pratto, Tatar, \& Conway-Lanz, 1999).

In other words, social dominance theory shares the belief that people will tend to align themselves either for or against the existing social hierarchy, and there is some attempt in the theory to explain how those alignments happen. According to the experts behind the theory, most people will tend to align themselves with viewpoints that favor their own personal way of viewing themselves. So, those who see themselves as insiders might generally favor the powerful forces, while those who see themselves as outsiders may tend to favor movements that might overthrow those forces.

The propositions of this theory are not far from the ethnic battle for dominance among the numerous ethnic groups in Nigeria especially among the three dominant ones even as it relates to census figures. The ethnic group with the highest population census figures uses it as a systemic institutional platform to discriminate and exercise dominance over the ethnic groups that have lower census figures. It is not to be over emphasized that whichever ethnic group that control the highest population controls the greater share of the national resources respective of the ethnic group that actually needs the resources at that time to foster development. Since, population figure are the yardstick with which national resources and political representation are shared, each ethnic group battle to inflate census figure in order to keep dominating the other ethnic groups with the advantages of socioeconomic and political dominance. This is what social dominance theory calls chronic group-based oppression which is driven by systematic institutional and individual discrimination. Also, this behaviour of dominance is always legitimatized by the ethnic group that the census figures favours while the one that it does not favour keep fighting for ways to turn the advantage to its own side. In social dominance theory, it is known as legitimizing myths. The hierarchy-enhancing legitimizing myth contributes to greater levels of group-based inequality while hierarchy-attenuating legitimizing myths contributes to greater levels of group-based equality. This is what usually characterized the outcome of past census in Nigeria where different states and regions tend to reject or accept census figures on the bases that it favours them or not. For instance, the battle of acceptance and rejection between Lagos state of Nigeria and Kano state in the last census of 2006 is a clear indication of this fact. Therefore, census figures in Nigeria since it is seen as a legal tender of the nation have always been used as an instrument of dominance instead of an instrument of sustainable development.

\section{Symbolic Interactionism Theory}

Symbolic interactionism is one of several interpretive approaches to social science research. This approach stems largely from the teachings of Mead (1934) but it was Blumer (1969) who coined its name and who proved influential in developing it into a theoretical perspective that is concerned with the genesis and evolution of meaning and identity. Three basic assumptions underpin Blumer's formulation of symbolic interactionism are:

1. That human beings act toward things on the basis of the meanings that thing $\mathrm{s}$ have for them.

2. That the meaning of such things is derived from, and arises out of, the social interaction that one has with one's fellows.

3. That these meanings are handled in, and modified through, an interpretive process used by the person in dealing with the things he encounters.

Other researchers including Maines (1977) and Stryker (1981) have extended these ideas, and because symbolic interactionism has thus evolved over the years, it is now an influential school of thought in social science research (Prasad 1993).It is important to note that symbolic interactionism is not concerned only with the study of symbols. The term "symbolic" refers to a basic premise that humans live in a world of objects (e.g., physical as well as social objects) that do not have intrinsic meanings. Instead, the meanings of objects arise out of the interpretations that people assign to them during the course of everyday social "interactions" with others. Out of these interactions, shared as well as local (to the actor) meanings emerge but are always subject to the possibility of change. This continuing process of interpretation takes place primarily using the shared symbols of language. People make sense of their world using symbols which convey the meanings of different objects, and these meanings (including the concept of self) in turn influence people's actions toward the objects (Swan \& Bowers1998).

Population census is generally seen by countries as an information base that aid planning and development but 
from the Nigeria experience it is seen as a symbol of political weapon to be used to take undue advantage of the other ethnic groups. This is what one of the assumptions of the theory of symbolic interactionism means when it says that human beings act toward things on the basis of the meanings that these things have for them. The only meaning that an average Nigeria gives to any form of headcount is that it is a room to battle for higher figures so that his ethnic origin will get the highest allocation from the national resources. Also, this perception of census figures as an instrument of domination among the different states in Nigeria has stood the test of time because the primordial ethnic sentiment is still dominant the domain of our practice of federalism. This means that the trend may continue for a long time because the younger generation has been socialized into this consciousness of ethnic sentiment and superiority. This reflects the theory of proposes that the meaning of such things is derived from, and arises out of, the social interaction that one has with one's fellow

\section{Challenges of Population Census on Sustainable Development in Nigeria.}

In a heterogeneous society like Nigeria where population size of each region is important in determining their political and economic status. The elite are often over-zealous about the value and important of population census, and they always do anything, not only to enumerate all their people, but also engage in various illegalities: electoral violence, falsification and manipulation of population figures (Stallings, 2006). Every population census held in Nigeria before and after independence has ended in national controversy, strong allegations of population falsification and in fact no general consensus among the populace as to the size of the total population of Nigeria (Eniayejuni, A. T. and Agoyi, M, 2011).

This scenario clearly mirrors ethnic battle for dominance especially between the three dominant ethnic groups as it relates to census figures in Nigeria. The ethnic group with the highest population census figures uses it as a systemic institutional platform to exercise dominance over the ethnic over others. Since, population figure are the yardstick with which national resources and political representation are shared, each ethnic group battle to inflate census figure in order to keep dominating the other ethnic groups with the advantages of socioeconomic and political resources. The result is chronic group-based oppression which is driven by systematic institutional and individual discrimination. Thus, census figures in Nigeria has become a kind of legal tender of the nation which have always been used as an instrument of dominance instead of an instrument of even or sustainable development(Odimegwu,2013). Demographic manipulation in the words of Odimegwu (2013) deleteriously rubs off on all facets of a country's national life as a questionable headcount inevitably undermines the totality of socio-economic development in a country. According to Odimegwu (2013), there is no doubt that faulty population figures drastically affect planning and, invariably, development. This is largely at the root of the country's poor human development index and overall backwardness in most parameters of national transformation. At the heart of the unreliable censuses over the years are the twin sore points: ethnicity, religion and $t$ hese two indicators have remained the core issues because of the struggle for supremacy on both grounds by the three major ethnic groups in the country. The clamour for supremacy by the three combative ethnic behemoths in the country must be confronted if the country is to advance in citizen data collation (Odimegwu,2013).

Unfortunately, the government has failed to harness the importance of population census for planning, progress and development. Nigerian national population census has been a victim of intense elite contestation for political and economic power, accusation of regional bias and favouritism, popular distrust,

resistance and widespread suspicion of the census results (Diamond, 1988). The National Population Commission (NPC) has admitted that it does not have accurate figures on Nigeria's population because the various estimates that have been presented by the commission in the past have been mired in controversy (Oyedele, 2013). Odimegwu (2013) further vehemently maintained that unless the census challenge is comprehensively managed and grey areas resolved, Nigeria will continue to wallow in the milieu of socioeconomic quagmire arising from blind and unrealizable projections. It is certain that the country is rapidly getting overpopulated. The far-reaching implication of this untoward manifestation is the stretching of the country's collapsing social infrastructure (Odimegwu, 2013)

Besides these challenges, there is the need to reposition census in Nigeria for sustainable development .The perception of headcounts as battle platform for interethnic competition for socioeconomic and political resources in Nigeria has remained daunting. This perception has stood the test of time because primordial ethnic sentiments are still dominant in the country. This trend may continue for a long time because the younger generation has been socialized into the consciousness of ethnic sentiments and superiority(Odimegwu, 2013). Future successful census exercises in Nigeria thus lie in value change, reorientation and strong institutional mechanisms to ensure credible census data for sustainable development in the country .Consequently, information about ethnic group, language, and religion which tend to influence tensions and inflation of census data in Nigeria must continue to be ignored in future census takings. Furthermore futures censuses in Nigeria cannot yield expect desirable and credible data without the adoption of improved ktechnology. This is an information and technological age and there is the need for transformation of census exercise to embrace new technologies to 
yield credible data for sustainable development in Nigeria.

\section{Conclusion}

National population census exercises have had a history of enormous challenges in Nigeria. These challenges affect the credibility and usefulness of census data for sustainable development in Nigeria. Census should be seen as a planning instrument rather than political weapon. With the giant strides being made in all spheres of the nation's development, census should be made a priority in Nigeria in her quest for socioeconomic transformation and development. Census is of great value and population data is sine qua non to sustainable development.

\section{Recommendations}

Presently, there is an increased awareness of population issues and the need to integrate population elements into development planning has become urgent in Nigeria. It is time for Nigeria government to recognize the importance of population factors in national development. The following specific recommendations are put forward:

1. The government should de-politicize the use of census figure by embarking on nationwide re-orientation campaign on the importance of census for common national development.

2. Questions about ethnic group, language and religion which trigger tension and inflation of census data should continue to be removed from the census questionnaire in Nigeria.

3. NPC should make use of relevant professionals in conducting the census exercise.

4. NPC should re-train their staff on massive application of "new" technologies such as Satellite Imagery, remote sensing techniques, machine readable forms, and other ICT devices used in conducting census

5. The government should adherence to 10 years interval in conducting census exercise in Nigeria.

6. The NPC should strengthen the vital registration of birth, death ,and migration, and others forms of data capturing that will greatly enhance fair estimation and updating of population and household data in Nigeria.

7. Government should review the laws as they affect headcount in the country to empower the National Population Commission to conduct future credible census exercise.

\section{References}

[1]. Blumer, H (1969), Symbolic Interactionism: Perspective and Method, Englewood Cliffs, NJ:Prentice-Hall

[2]. Butler, R.A. (2013). Mongabay.com Retrieved from current June 29 from http://www.mongabay.com

[3]. Brown, D. E. (1991). Human universals. New York: McGraw-Hill.

[4]. Chinsman, B. (1995). Putting People First: A Statement to the Journalist Encounter at the Horld Summit for Social Development.

[5]. Diamond, L.J (1998) Class, Ethnicity and democracy in Nigeria: The Failure of the First Republic. Syracuse, New York: SyracuseUniversity Press, pp. 131-133

[6]. .Enieayejuni, A.T. and Agoyi M. (2011). "A Biometric Approach Census and National Identification in Nigeria: A Prerequisite for Planning and Development" in Journal of Asian- Transactions on Basic and Applied Sciences vol.1 Issue 05 www.asiantransactions.org/atbsvol01Issue05.htm

[7]. Gurr, T.R.(1970). Why Men Rebel. New Jersey, US: Princeton University Press, pp. 24

[8]. Maines, D (1977), 'Social organization and social structure in symbolic interactionist thought', Annual Review of Sociology, vol.3.

[9]. Mathews, M.P. (2002) Nigeria: Current issues and historical background. Hauppauge, New York: Nova Publishers, pp. 159.

[10]. Mead, GH (1934), Mind, Self and Society, Chicago: University of Chicago Press.

[11]. Mimiko, F. (2006) Census in Nigeria: The Politics and the Imperative of Depolarization African and Asian Studies, vol. 5, Is. 1, pp. 1-22, 2006.

[12]. Mitchell, M. \& Sidanius, J. (1995). Social hierarchy and the death penalty: A social dominance perspective. Political Psychology, 16, 591-619.

[13]. National population census-ethnicity, religion and their possible impact on it (2013)Retrieved on April 24, 2013 from www.doublegist.com.

[14]. Odimegwu, F. (2013)."Nigerian Census Challenge: Our Report" The Sun $11^{\text {th }}$ August 2013, P.1

[15]. Odunfa, S. (2006). Nigeria's counting controversy. Bbc. co.uk BBC News.

[16]. OECD, (1995). Participatory development and good government, Paris, France.

[17]. Okolo, A. (1999)."The Nigerian Census: Problems and Prospects"The American Statistician 53; $321-325$ in J.R. Weeks (2008). Population: An Introduction to Concepts and Issues tenth edition .London: ADWORTH Ltd.

[18]. Olokor, F. (2013, April 16). 2016 census: FG insists on accurate data quality. Punch Newspaper Nigeria Retrieved from http://www.punchng.com

[19]. ORC Macro.(2004) "Demographic and Health Survey" www.measuredhs.com, accessed (2006) in .R.Weeks (2008). Population: An Introduction to Concepts and Issues tenth edition. London: ADSWORTH Ltd.

[20]. Osinaike, R. Aiyeola, T and Alao, S. (2006). In Search of True Population Figure, Guardian newspaper limited, Lagos.

[21]. Ottong, J.G. (1983). Htt://www.onlineNigeria.com/population retrieved on 14/11/2013

[22]. Oyedele, D. (2103), "NPC: We lack accurate figures on Nigeria Population" Thisday Newspaper, April 19 p. 1 Retrieved from online on $30 / 06 / 13$.

[23]. Pinker, S. (2002). The blank slate: The modern denial of human nature. New York: Penguin.

[24]. Prasad, P (1993), 'Symbolic Processes in the Implementation of Technological Change: A Symbolic Interactionist Study of Work 
Computerization', Academy of Management Journal, vol.36, no.6.

[25]. Pratto, F. (1999). The puzzle of continuing group inequality: Piecing together psychological, social and cultural forces in social dominance theory. Advances in Experimental Social Psychology, 31, 191-263.

[26]. Sidanius, J. \& Pratto, F. (1999). Social dominance: An intergroup theory of social hierarchy and oppression. Cambridge, UK: Cambridge University Press.

[27]. Skerry, P. (2000). Counting on the census?: race, group identity and the evasion of politics. Massachusetts, US: Brookings Institution Press, pp. 11.

[28]. Stallings, W. (2006) Cryptography and network security, New Jersey, US: Prentice Hall.

[29]. Stock, R.F. (2004). Africa South of the Sahara: a geographical interpretation. New York, US: Guilford Press, pp.410-41.

[30]. Stryker, S. (1981), 'Symbolic interactionism: Themes and variations' in M Rosenberg and R Turner (Eds.), Social psychology, New York: Basic Books.

[31]. Swan, J.E. \& Bowers, MR (1998), 'Services quality and satisfaction: the process of people doing things together', Journal of Services Marketing, vol.12, no.1.

[32]. United Nations Development Programme UNDP, (2006). Human Development Report, New York Oxford University Press.

[33]. Williams, M. (2003) Citizenship education and lifelong learning: power and place. Hauppauge, New York: Nova Publishers.

[34]. Weeks, J.R. (2008).Population: An Introduction to Concepts and Issues tenth edition.London:WADSWORTHLtd

[35]. http://business.highbeam.com/4438/article-1G1-162101588/report-nigeria-national-population-commission-2006)

[36]. www.population.gov.ng retrieved on 30 June, 2013 (www. Nigeriacensus-history.com 